\title{
Evidence of reworking and resuspension of carbonates during last glacial maximum and early deglacial period along the southwest coast of India
}

\author{
Kamlesh Verma and M SudhaKaR* \\ National Center for Antarctic and Ocean Research, Vasco da Gama, Goa 403 804, India. \\ *e-mail: msudhakar@ncaor.org
}

\begin{abstract}
A gravity core collected from the upper slope of southwest of Quilon at a water depth of $776 \mathrm{~m}$ (Lat: $8^{\circ} 12^{\prime} 263^{\prime \prime} \mathrm{N}$, Long: $76^{\circ} 28^{\prime} 281^{\prime \prime} \mathrm{E}$ ) was analysed for texture (carbonate free), calcium carbonate and organic carbon. Variation in silicic fraction seems to be controlled by silt, i.e., enrichment from $15 \mathrm{ka} \mathrm{BP}$ to $10 \mathrm{ka} \mathrm{BP}$ and then constant in Holocene. Below $15 \mathrm{ka} \mathrm{BP}$, the silicic fraction gets depleted compared to the Holocene section with a minimum around $21 \mathrm{ka}$ BP. Clay content remains nearly constant except in the Holocene where it shows an enrichment. Carbonate content of less than 63 micron when computed by subtracting coarse fraction content from the total carbonate suggests that the total carbonates are mainly concentrated in the finer fraction. All these carbonate phases show an inverse relationship with silicic fraction except in Holocene. Below $15 \mathrm{ka} \mathrm{BP}, \mathrm{CaCO}_{3}$ dominates in sediments comprising more than $65 \%$, such an increase is also seen in the coarse fraction. Coarse fraction from these sections contains abundant nodular type aggregates encrusting small forams. This period is marked by a high sedimentation rate comparable to Holocene. These parameters suggest that the productivity and precipitation have increased in the Holocene due to the intensification of the southwest monsoon. During the last glacial maximum and early deglacial period the high sedimentation rate indicates redeposition of the carbonates from the existing carbonate lithofacies situated between Quilon and Cape Comorin probably due to the slope instability.
\end{abstract}

\section{Introduction}

Sediments are the natural repositories of information about the past. Various researchers have been archiving this information in order to study the past variation of climate and sedimentary processes. Pertaining to this, a large amount of palaeo data exists especially from the Arabian Sea. These studies reveal that in general, summer monsoon is stronger during interglacials than glacials (Prell et al 1992; Agnihotri et al 2003) and winter monsoon is stronger than present during the early deglacial period (Tiwari et al 2005) and during the LGM (Duplessy 1982). It is very well known that both the biotic and abiotic components of sediments seem to be related to the monsoonal and or climatic phenomenon prevailing during that time. Various signatures called as proxies are established for deducing these climatic variations. Among these proxies calcium carbonate and organic carbon (Thamban et al 2001) have been widely studied and validated by various sediment trap data (Nair et al 1989). Sediment trap study shows a correlation of these proxies with monsoonal strength. But the differential reaction of productivity proxies in different regions leads to contradictory conclusions on the relation between productivity and monsoonal strength. This contradiction arises due to several sedimentary, geologic and oceanographic processes that occur differently

Keywords. Holocene; last glacial maximum (LGM); deglacial. 


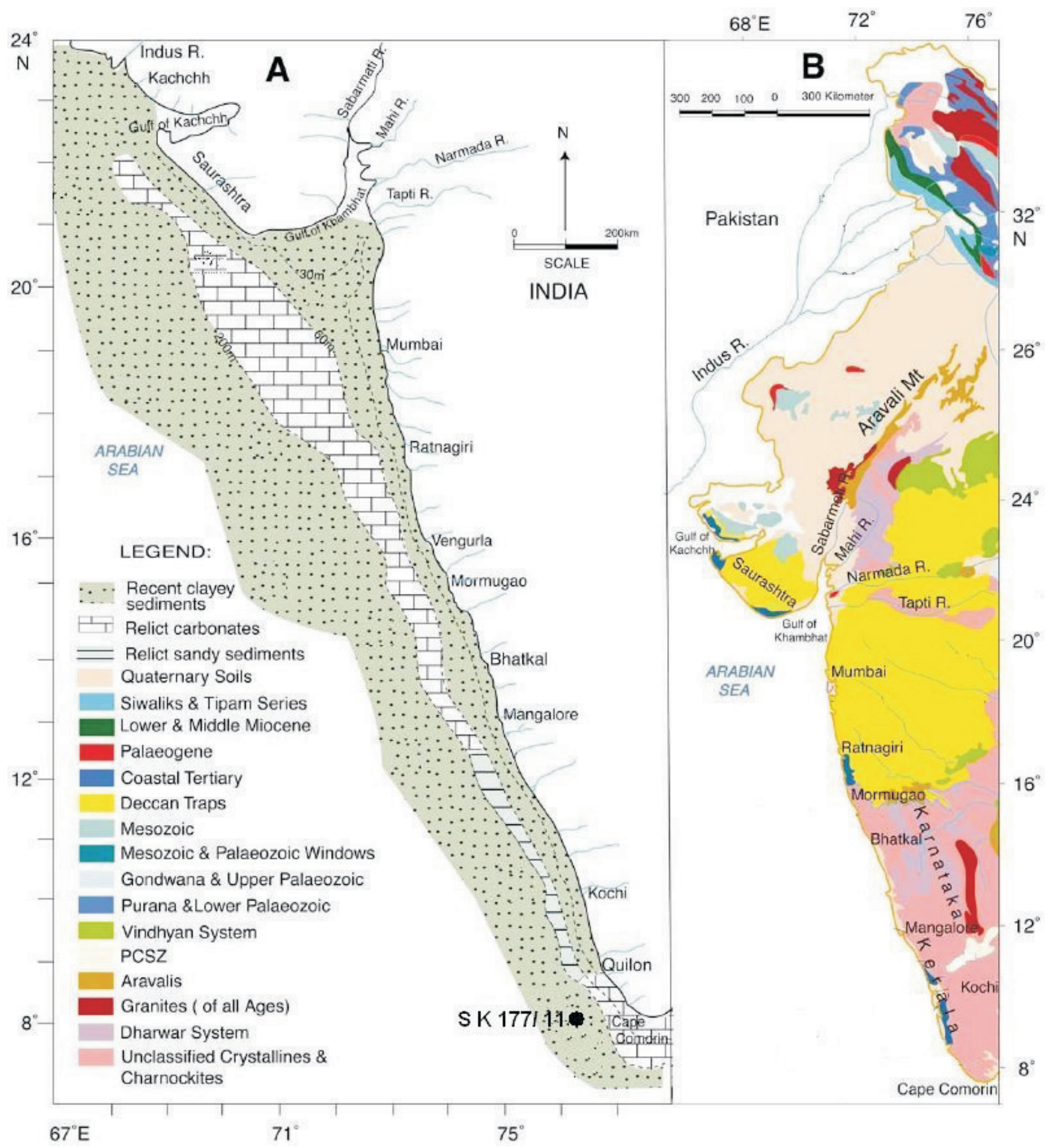

Figure 1. (A) Map showing core location and surficial geology of continental shelf and slope. (B) Geology of western India (Anonymous 1965). This map is taken from Kessarkar et al (2003).

in different locale. Pattan et al (2003) obtained low calcium carbonate during the glacial period because of dilution from terrigeneous input. Similarly Thamban et al (2001) observed low organic carbon during enhanced monsoonal activity due to stratification of ocean surface by fresh water leading to suppression of upwelling. Therefore it is suggested that before drawing any conclusion from these proxies, various processes acting in that region should be identified and the origin of these proxies should be ascertained, i.e., whether they are in situ or reworked/resuspended, otherwise it could lead to an erroneous interpretation pertaining to paleoclimatic/paleomonsoonal studies. 


\section{Materials and methods}

A gravity core measuring $3.63 \mathrm{~m}$ SK-177/11 (lat. $8^{\circ} 12^{\prime} 263^{\prime \prime} \mathrm{N}$ and long. $76^{\circ} 28^{\prime} 281^{\prime \prime} \mathrm{E}$ ) from a water depth of $776 \mathrm{~m}$ along the southwestern slope of Quilon (figure 1) was collected, sub-sampled at 1 to $2 \mathrm{~cm}$ interval and packed in a polythene bag for further analysis. The core site is located within the present day oxygen minimum zone, i.e., 250-1250 m (Wyrtki 1971). The lithology of the core shows silty clay with yellowish green colour from $0-158 \mathrm{~cm}$ and grayish green thereafter.

Textural analysis (carbonate free) was done on selected samples. About 8-10 gm of dried sample were wet-sieved by a 63 -micron sieve and collected in a measuring cylinder. Prior to sieving, carbonate and organic matter were removed by adding $1 \mathrm{~N} \mathrm{HCl}$ and $10 \mathrm{ml}$ of $\mathrm{H}_{2} \mathrm{O}_{2}$ respectively. The textural analysis was carried out following standard techniques (Folk 1968).

Calcium carbonate was determined by the EDTA titration method after digesting 100-150 mg of weighed sample in $2 \%$ acetic acid (Barnes 1959). Organic carbon content was measured by the wet oxidation method (El Wakeel and Riley 1957). The reproducibilities measured from the duplicate samples after every 10 samples for both calcium carbonate and organic carbon were found to be better than 5\%. For coarse fraction study, 8-10 gm of dried sample were wet-sieved by 63 micron after removal of organic matter with $10 \mathrm{ml} \mathrm{H}_{2} \mathrm{O}_{2}$. Coarse fraction was collected and weighed after drying.

The chronology for the core samples was obtained (shown in table 1) from Pandarinath et al (2004). The ages shown in table 1 were calibrated with the help of the programme Calib 4.1 (INTCAL 98) (Stuiver et al 1998) except those marked with an asterisk. These uncalibrated ages of Pandarinath et al (2004) were later calibrated using the Bard polynomial (Bard 1998) because it was beyond the range of the latest calibration curve INCAL04.

Table 1. Calibrated dates and sedimentation rates (Pandarinath et al 2004).

\begin{tabular}{ccccc}
\hline Sl. no. & $\begin{array}{c}\text { Sample } \\
\text { interval } \\
(\mathrm{cms})\end{array}$ & $\begin{array}{c}\text { Depth } \\
(\mathrm{cms})\end{array}$ & $\begin{array}{c}\text { Age } \\
(\mathrm{ka} \mathrm{BP})\end{array}$ & $\begin{array}{c}\text { Sedimenta- } \\
\text { tion rate } \\
(\mathrm{cm} / \mathrm{yrs})\end{array}$ \\
\hline 1 & $54-56$ & 56 & 2.885 & 0.019 \\
2 & $100-105$ & 105 & 5.95 & 0.016 \\
3 & $150-155$ & 155 & 8.69 & 0.018 \\
4 & $200-205$ & 205 & 16.04 & 0.007 \\
5 & $250-255$ & 255 & 18.99 & 0.017 \\
6 & $300-305$ & 305 & $26.947^{*}$ & 0.006 \\
7 & $360-365$ & 365 & $33.75^{*}$ & 0.009 \\
\hline
\end{tabular}

*These dates are calibrated using Bard Polynomial (Bard 1998), others are calibrated following INTCAL 98.

\section{Results}

Based on the sedimentation rate (shown in figure 2c), an age depth model was created by interpolating the dated points. It is evident from the sedimentation rate that during the Holocene sedimentation rate had increased three-fold relative to pre-Holocene, except at $19 \mathrm{ka} \mathrm{BP}$ when it increased drastically. Since the mass accumulation rate is sensitive to the linear sedimentation rate (Clemens et al 1987) the wt\% of different parameters are discussed to avoid any bias due to LSR.

Variation of textural pattern (carbonate free) shown in figure $2(a, b)$ suggests that the core is silty clay with average $30 \%$ clay and $12 \%$ silt. Sand fraction being insignificant can be neglected. Temporal variations of silt and silicic fractions show three distinct zones, i.e., Holocene, 15-10 ka BP, and below $15 \mathrm{ka}$ BP. In the Holocene section, these two parameters show enrichment of silt and silicic fraction, between 15 and $10 \mathrm{ka}$ BP there is a transition from low value to high value for both silt and silicic fractions. Below this, silt and silicic fractions remained low with the lowest value at $21 \mathrm{ka} \mathrm{BP}$ and the highest at $26 \mathrm{ka}$ BP. It is interesting to note that silicic fraction is largely controlled by silt because clay remained near constant throughout the age except in Holocene where it shows a slight enrichment.

During the Holocene, organic carbon (figure 3d) shows enrichment alongwith the coarse fraction (figure 3c) whereas total carbonate content (figure $3 \mathrm{a}$ ) shows a slight increasing trend. Between 15 and $10 \mathrm{ka}$, the carbonate content shows a decreasing trend and below this transition period it dominates in the sediments with an average of $67 \%$. Similarly, organic carbon showed a slight enrichment between $15-10 \mathrm{ka}$ and $26-15$ ka but remained low compared to the Holocene. The carbonate percentage of finer fraction as shown in figure 3(b) is computed by subtracting coarse fraction from the total carbonates. It indicates that total carbonates are mainly concentrated in finer fraction. Coarse fraction along with total carbonates and finer fraction carbonates increases below 15 ka where coarse fraction reaches a maximum value in $23 \mathrm{ka}$. Visual examination of coarse fraction under binocular microscope reveals the presence of nodular aggregates encrusting small forams (figure $4 \mathrm{a}, \mathrm{b}$ and c). This is very common from the samples of this section. The dominance of the carbonate phase between 23 and $15 \mathrm{ka}$ along with the increased sedimentation rate (figure 2c) points towards the rapid accumulation of carbonate, probably due to reworking and resuspension. This fact is also supported by the presence of nodular aggregates in coarse fraction which is commonly found in the existing carbonate lithofacies between Quilon and Cape Comorin. 


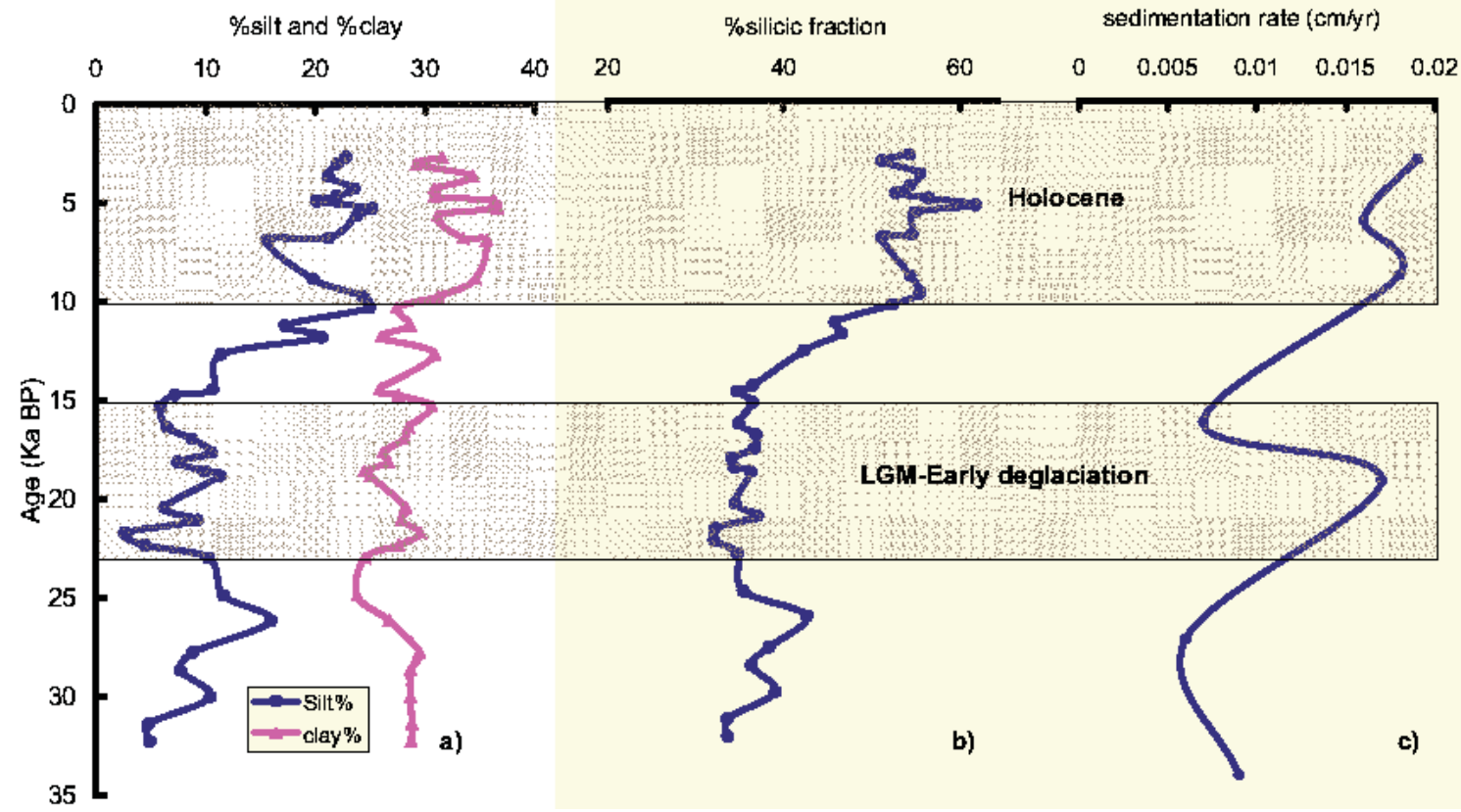

Figure 2. (a) Textural pattern; (b) $\%$ silicic fraction and (c) sedimentation rate (cm/yr).

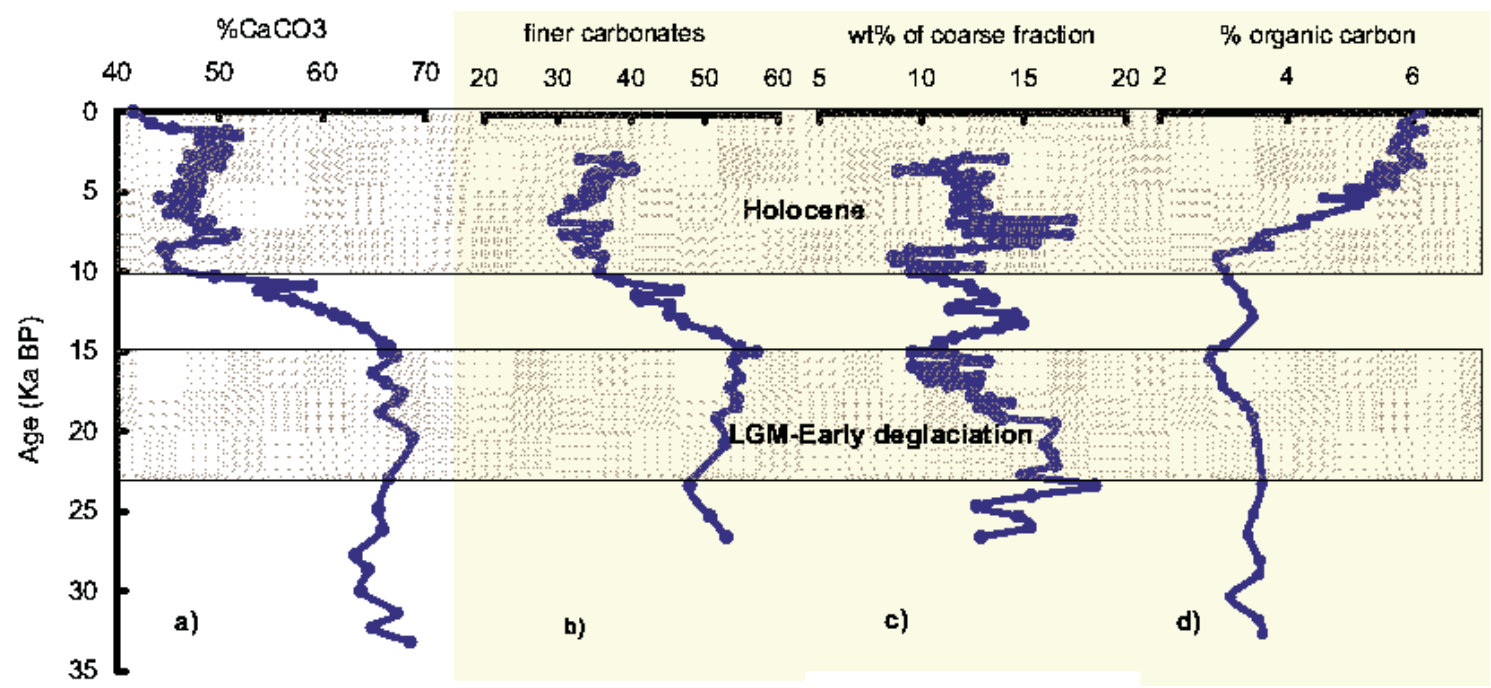

Figure 3. (a) \% Total carbonates; (b) finer fraction carbonates; (c) \% coarse fraction and (d) \% organic carbon.

\section{Discussion}

\subsection{Last glacial maximum - early deglacial period}

It is evident from figure 2(a) and (b) that during 23-15 ka silt and silicic fraction remained low with the lowest value at $21 \mathrm{ka}$ which corresponds to LGM when the sea level was lower than the present sea level (Rao et al 2003) in the QuilonCape Comorin region. Such discrepancy of low detrital material inspite of the exposed shelf indicates the reduced strength of erosion because of weakened SW monsoon. However, though clay is unaffected by this the silt gets reduced, this could be due to the contribution from Varkala beds (ferrugeneous sandstone with clay intercalation) and clay being lighter gets transported further offshore to the deposition site. In contrast to this, one can expect clay minerals from dust, as the climate was arid during this period and in this region. This possibility could be ruled out by checking figure 2(b) where the silicic fraction is lowest and the variation in clay (figure 2a) content is not significant suggesting any change in provenance. This inference is also supported by the study of Kessarkar et al (2003) 


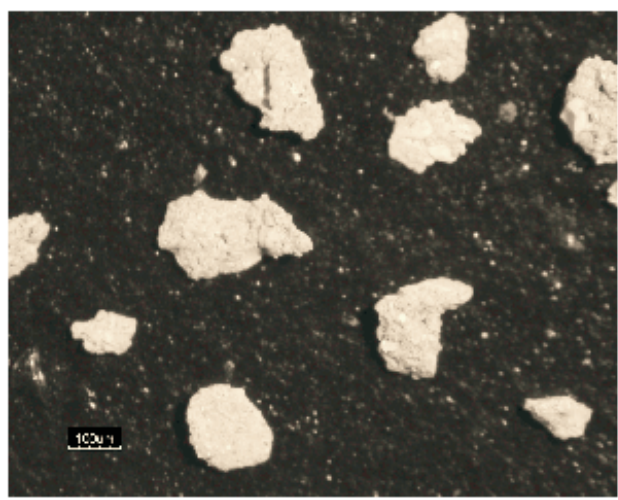

(a)

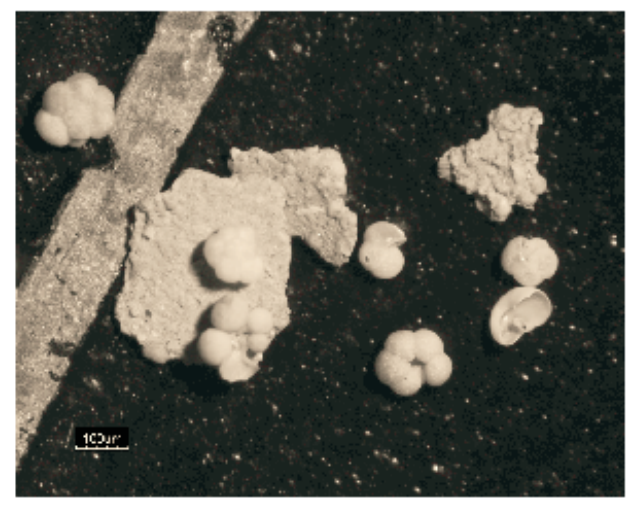

(b)

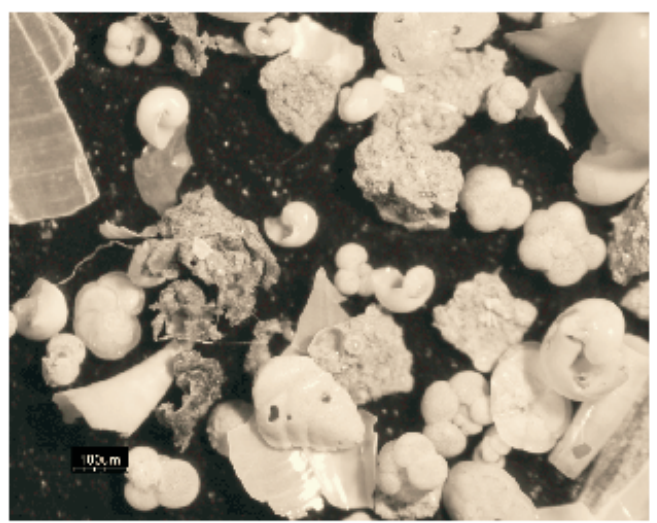

(c)

Figure 4. (a, b and c) Photomicrographs showing calcareous nodular aggregates $(\operatorname{mag} \times 11.25)$.

who have used ${ }^{87} \mathrm{Sr} /{ }^{86} \mathrm{Sr}$ ratio and $\mathrm{Nd}$ isotope as a tracer for identifying the transport pathway of clay minerals and denied any change in provenance or transport pathway through the glacial-interglacial time period.

Among productivity proxies, organic carbon remained low in this period and can be attributed either to low silicic fraction or decreased overhead productivity due to a weak SW monsoon (Prell et al 1992; Sarkar et al 2000a; Sirocko et al 2000). But studies from this region show that overhead productivity has increased in this period in relation to the NE monsoonal wind leading to convective overturning and subsequent injection of nutrients to the mixed layer depth (Sonzogni et al 1998; Cayre and Bard 1999; Thamban et al 2001). However, from this proxy it is not possible to ascertain whether the NE monsoon was strong or weak as this could be a possibility that the overhead productivity had increased but not been preserved due to low silicic fraction because finer detrital materials such as silt and clay effectively scavenge and preserve organic matter. But, from detrital input it is certain that the intensity of SW monsoon was weak during LGM-early deglacial period. Interestingly in this period sedimentation rate was high, comparable to that of Holocene peaking around $19 \mathrm{ka}$. Such increase is also seen in carbonates (total carbonates, finer carbonates and coarse fraction). Therefore the dominance of carbonate phase in this time-slice represents reworking/resuspension from the already existing carbonate lithofacies between Quilon and Cape Comorin. It can be supported by two reasons - firstly, the sedimentation rate which has increased abruptly is not reflected in the concentration of silicic material rather it has decreased and been diluted by the carbonates. Secondly, the coarse fraction study shows some nodular aggregates with encrusted forams and broken fragments of microfossils as shown in figure 4 (a, b and c). As already mentioned, during this period the sea level was low which might have triggered slumping of these pre-existing carbonate lithofacies between Quilon and Cape Comorin (Rao et al 1997).

\subsection{Period from $15-10 \mathrm{ka}$}

The period between 15 and $10 \mathrm{ka}$ is globally characterized by the melting of ice sheets and the subsequent increase in sea level in two pulses, of which melt water pulse 1 (14 ka) is very strong 
(Fairbanks et al 1989). In this time domain concentration of silicic fraction increases gradually. This is attributed to the gradual increase in SW monsoonal strength due to the deterioration of ice sheets thereby creating a thermal gradient between land and ocean necessary for SW monsoon. Strengthening of SW monsoon is also reflected in increased sedimentation rate. Although a slight increase in the concentration of organic carbon is also noticed, it could be due to sedimentation rate and silicic fraction. Further, it has been observed from the coarse fraction content that the calcareous aggregates are completely absent from this section. This absence of calcareous aggregates along with the decreased carbonate content indicates the absence of reworking.

\subsection{Holocene}

It has been well established that during the Holocene time, melting of ice sheets was almost complete. Due to this, the thermal gradient started developing between land and ocean resulting in enhanced southwest monsoonal wind which carries moisture towards the Indian subcontinent and results in heavy rains. This strong wind introduces nutrients in the surface mixed layer of Arabian Sea either by the upwelling or by deepening of mixed layer (Nair et al 1989). Phytoplankton, microorganisms, etc., utilize these nutrients for their growth and finally contribute to the pool of sedimentary organic carbon and calcium carbonate. This ocean wind interaction is very well reflected in our study as seen from figure 3 where organic carbon content increases from 3-6\% (figure 3d) in this section. Regarding the origin of organic matter, various researchers reported that the organic carbon of this region is predominantly of marine origin using different tools such as $\mathrm{C} / \mathrm{N}$ ratios (Paropkari et al 1987, 1992, 1993), organic geochemistry (Caratini et al 1981) and $\delta^{13} \mathrm{C}$ (Fontugne and Duplessy 1986). Moreover in present day environment, it has been observed that there exists a similarity between water column productivity and underlying sediments both being high in the periphery of the Arabian Sea and low in the central part (Paropkari et al 1992). For e.g., in the study region, south of Cochin, water column productivity is high $>0.75 \mathrm{gC} / \mathrm{m}^{2} /$ day (Qasim 1982) and it is expected to be higher in sediments. Such high values are also seen in the analysis of this core, i.e., organic carbon varies from $3-6 \%$. This means that there is a correlation between water column productivity and analyzed productivity from the sediments specifically from this region. Therefore calculated productivity from sediments can represent past water column productivity. However, variables like sedimentation rate (Canfield 1994;
Agnihotri et al 2003) and oxygen minimum conditions (Summerhayes 1987; Paropkari et al 1993; Reichart et al 1997) also play an important role in organic carbon enrichment. Like organic carbon, coarse fraction also shows an enrichment exhibiting a positive correlation. This indicates that both organic carbon and coarse fraction represent productivity which has increased in this section. This is further supported by the coarse fraction study negating any role of reworking/resuspension to the core site because it does not contain any nodular aggregates as seen in the earlier section and the shells are relatively cleaner as compared to the coarse fraction of LGM-early deglacial period.

The increase in the intensity of SW monsoon is also seen in detrital input (figure 2a, b). These detrital materials have been brought down to the core site by numerous monsoon fed rivers, streams and channels of this region which have regained their full strength due to the increase in summer monsoon intensity.

Upon considering all these observations it seems that the organic carbon, calcium carbonate of this core is predominantly of marine origin and free from reworking during Holocene. Therefore the increase in concentration of coarse fraction, organic carbon, silicic fractions and the sedimentation rate (figures $3 \mathrm{c}, 3 \mathrm{~d}, 2 \mathrm{~b}$ and $2 \mathrm{c}$ ) is an artifact of southwest monsoonal intensity leading to nutrient injection into the sea surface through wind mixing/upwelling processes and erosion and subsequent deposition by fluvial processes. This resulted in the phytoplankton and calcareous micro-organisms bloom which finally settled down into the sediments as organic carbon and calcium carbonate along with terrestrial detritus. Our result of strengthening southwest monsoon in Holocene is in agreement with earlier results (Van Campo et al 1982; Van Campo 1986; Naidu 1998; Sarkar et al 2000b).

\section{Conclusion}

The sediment core collected from a water depth of $776 \mathrm{~m}$ southwest of Quilon covers a timespan of $33.75 \mathrm{ka}$. Analyzing for the basic sedimentological parameters used for paleomonsoonal/paleoclimatic interpretation, it shows the following relation:

- During the Holocene, organic carbon, coarse fraction and $\mathrm{CaCO}_{3}$ seem to be of marine origin, free from dilution effect and are correlated with the intensity of monsoon. The concentration of these fractions suggests intensification of southwest monsoon in this period. The effect of OMZ in organic carbon enrichment in glacialinterglacial time scale would have been the same as the site remained in OMZ throughout. 
Although from figure $2(\mathrm{a}, \mathrm{b}, \mathrm{c})$ organic carbon seems to be controlled by terrigenous input, on combining all proxies it can be inferred that the overhead productivity increased during the Holocene.

- Organic carbon shows a slight enrichment whereas terrestrial input increases gradually from a period of $15-10 \mathrm{ka}$ indicating an early strengthening of SW monsoon.

- Increase in sedimentation rate during LGMearly deglacial period coupled with the dominance of carbonate phase is attributed to the reworking and resuspension of calcareous sediments probably due to the slope instability owing to the low sea level stand.

\section{Acknowledgements}

The authors thank Rasik Ravindra Director, National Center for Antarctic and Ocean Research (NCAOR) and Secretary, Department of Ocean Development (DOD) for providing the ship time, and for their encouragement and support. We are also indebted to the anonymous reviewer and Dr A C Narayana, for his constructive comments. $\mathrm{KV}$ is thankful to DOD New Delhi for funding the NCAOR fellowship.

\section{References}

Agnihotri R, Sarin M M, Somayajulu B L K, Jull A J T and Burr G S 2003 Late Quaternary biogenic productivity and organic carbon deposition in the eastern Arabian Sea; Palaeogeogr. Palaeclimatol. Palaeoecol. 197 43-60.

Anonymous 1965 Gazetteer of India, Publications division, Ministry of Information and Broadcasting, Government of India; 1 p. 652.

Bard E 1998 Geophysical and Geochemical implications of the radiocarbon calibration; Geochem. Cosmochem. Acta. 62(12) 2025-2038.

Barnes H 1959 Apparatus and methods in Oceanography (London: Allan and Unwin) p. 341.

Canfield D E 1994 Factors influencing organic carbon preservation in marine sediments; Chem. Geol. 114 315-329.

Caratini C, Bellet J and Tissot C 1981 Microscopy of the Organic matter: Palynology and the Palynofacies. Organic geochemistry of the deep marine sediments; In: Orgon 4. Aden Gulf; Oman Sea. CNRS, Paris, pp. 265-307.

Cayre O and Bard E 1999 Planktonic foraminiferal and alkenone records of the last deglaciation from the eastern Arabian Sea; Quat. Res. 52 337-342.

Clemens S C, Prell W L and Howard W R 1987 Retrospective dry bulk density estimates from southeast Indian Ocean sediments - comparison of water loss and chloride ion methods; Mar. Geol. 76 57-69.

Duplessy J C 1982 Glacial to interglacial contrast in the Northern Indian Ocean; Nature 295 494-498.

El Wakeel S K and Riley J P 1957 Determination of organic matter in marine muds; J. Con. Int. Expl. Mer. 22 180-183.
Fairbanks R G 1989 A 17,000-year glacio-eustatic sea level record: influence of glacial melting rates on the younger Dryas event and deep-ocean circulation; Nature $\mathbf{3 4 2}$ 637-642.

Folk R L 1968 Petrology of Sedimentry rocks. Hemphills, Austin, p 177.

Fontugne M R and Duplessy J C 1986 Variations of the monsoon regime during the upper Quaternary: evidence from a carbon isotopic record of organic matter in northern Indian Ocean sediment cores; Palaeogeogr. Palaeoclimatol. Palaeoecol. 56 69-88.

Kessarkar P M, Rao V P, Ahmad S M and Anil Babu G 2003 Clay mineral and $\mathrm{Sr}-\mathrm{Nd}$ isotope of the sediments along the western margin of India and their implication for the sediment provenance; Mar. Geol. 202 55-69.

Naidu P D 1998 Driving forces of Indian summer monsoon on Milankovitch and sub-milankovitch time scales: A review; J. Geol. Soc. India 52 257-272.

Nair R R, Ittekkot V, Manganini S J, Ramaswamy V, Haake B, Degens E T, Desai B N and Honjo S 1989 Increased particle flux to the deep ocean related to monsoon; Nature 338 749-751.

Pandarinath K, Verma S P and Yadava M G 2004 Dating of Sediment layers and sediment accumulation studies along the western continental margin of India: A review; Int. Geol. Rev. 46 939-956.

Paropkari A L, Prakash Babu C and Mascarenhas A 1993 New evidence for enhanced preservation of organic carbon in contact with oxygen minimum zone on the western continental slope of India; Mar. Geol. 111 7-13.

Paropkari A L, Prakash Babu C and Mascarenhas A 1992 A critical evaluation of the depositional parameters controlling the variability of organic carbon in Arabian Sea; Mar. Geol. 107 213-226.

Paropkari A L, Rao Ch M and Murthy P S N 1987 Environmental controls on the distribution of organic matter in the recent sediments of the western continental margin of India; In: Petroleum geochemistry and exploration in Afro-Asian Region (eds) Kumar R K, Dwivedi P, Banerjie V and Gupta V (Balkema: Rotterdam) p. 347-361.

Pattan J N, Masuzawa T, Naidu P D, Parthiban G and Yamamoto M 2003 Productivity fluctuation in the southeastern Arabian Sea during the last $140 \mathrm{ka}$; Palaeogeogr. Palaeclimatol. Palaeoecol. 193 575-590.

Prell W L, Murray D W, Clemens S C and Anderson D M 1992 Evolution and variability of the Indian ocean summer monsoon: evidence from the western Arabian Sea drilling program; Geophysical Monograph 70 447-469.

Qasim S Z 1982 Oceanography of the Northern Arabian Sea; Deep-Sea Res. 29 1041-1068.

Rao V P, Rajagopalan G, Vora K H and Almeida F 2003 Late Quaternary sea level and environmental changes from relic carbonate deposits of the western margin of India; Proc. Indain Acad. Sci. (Earth Planet. Sci.) 112(1) 1-25.

Rao V P and Wagle B G 1997 Geomorphology and surficial geology of the western continental shelf and slope of India: A review; Curr. Sci. 73(4) 330-350.

Reichart G J, Dulk M D, Visser H J, van der Weijden C H and Zachariasse W J 1997 A $225 \mathrm{Kyr}$ record of dust supply, paleoproductivity and the oxygen minimum zone from the Murray ridge (northern Arabian Sea); Palaeogeogr. Palaeclimatol. Palaeoecol. 134 149-169.

Sarkar A, Ramesh R, Bhattacharya and Price N B 2000a Paleomonsoon and productivity records of $\delta^{18} \mathrm{O}, \delta^{13} \mathrm{C}$ and $\mathrm{CaCO}_{3}$ variations in the northern Indian Ocean sediments; Proc. Indain Acad. Sci. (Earth Planet. Sci.) 109(1) 157-169. 
Sarkar A, Ramesh R, Somayajulu B L K, Agnihotri R, Jull A J T and Burr G S 2000b High resolution Holocene monsoon record from the eastern Arabian Sea; Earth Planet. Sci. Lett. 177(3-4) 209-218.

Sirocko F, Dieter Garbe-Schonberg and Devey C 2000 Processes controlling trace element geochemistry of Arabian Sea sediments during the last 25,000 years; Global and Planetary Change 26 217-303.

Sonzogni C, Bard E and Rostek F 1998 Tropical sea surface temperatures during the last glacial period: a view based on alkenones in Indian Ocean sediments; Quat. Sci. Rev. 17 1185-1201.

Stuiver M et al 1998 INTCAL 98 radiocarbon age calibration, 24,000-0 cal BP; Radiocarbon. 40 1041-1083.

Summerhayes C P 1987 Organic rich Cretaceous sediments from the North Atlantic; In: Marine Petroleoum Source Rocks (eds) Brooks J and Fleet A J, Geol. Soc. Spec. Publ. 26 301-316.
Thamban M, Rao V P C, Schneider R R and Grootes P M 2001 Glacial to Holocene fluctuations in hydrography and productivity along the southwestern continental margin of India; Palaeogeogr. Palaeclimatol. Palaeoecol. 165 $113-127$.

Tiwari M, Ramesh R, Somayajulu B L K, Jull A J T and Burr G S 2005 Early deglacial (19-17 ka) strengthening of the northeast monsoon; Geophys. Res. Lett. 32 L19712.

Van Campo E 1986 Monsoon fluctuation in two 20,000 yr B.P. oxygen-isotope/pollen records of southwest India; Quat. Res. 26 376-388.

Van Campo E, Duplessy J C and Rossignol-Strick M 1982 Climatic conditions deduced from a 150,000 yr oxygen isotope-pollen record from the Arabian Sea; Nature 296 $56-59$.

Wyrtki K 1971 Oceanographic Atlas of the International Indian Ocean Expedition; Washington D C, National Science Foundation, p. 531. 